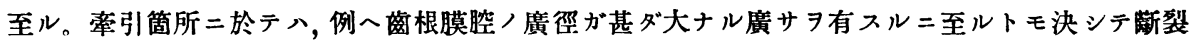
ヨ見ラル、コトナシ。

骨二於ヶル機轉八厴迫側二於テハ吸收ニョリテ示サル。勿論吸收八嫄迫セラレタル畗牙二對シ テ場所ヨ求ムル意味二於テ起ルモノナリ。同時二修復が起ル, 之モ勿論骨梁ノ肥厚及ビ䑤加

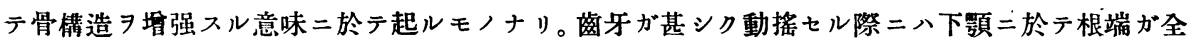
ク原始的厚徑二達スル迄額骨體，著シキ吸收が起ルコトアリ。骨㵦中及ビ外表面／甚シキ改造八

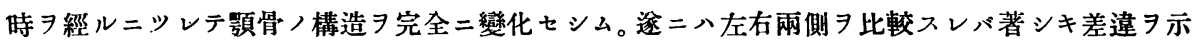
スニ至ル。又常二骨破壤が起リッ、アリ，郎チ背後吸收ニヨル接解部，遊離八幼若動物二於テハ 老衰動物ヨリ八急速ニ起ルモノナリ。

齒牙表面卜骨表面卜八資擔過重二對スル反應が異ル，此八點八臨牀的觀察ト全クョク一致ス。 負擔過重が二週間持續スル時八根面上規則的二必ズ吸收ヨ來スベシ。幼若ナル寚牙八，特二長期 , 負擔過重, 際ニモ甚シキカガ働クニ拘ラズ, 吸收二對シテ八著シキ抵抗

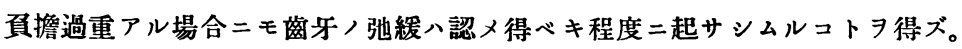

以上ノ成績 $コ$ 各實驗例二就テー々詳細二述ベタル後, 再ビ總括的二蓠根膜ニ於ヶル變化, 骨，

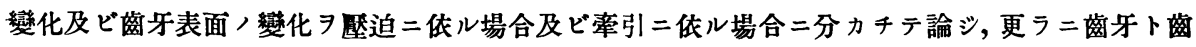

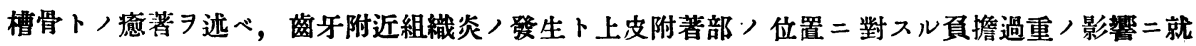

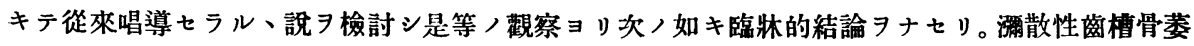

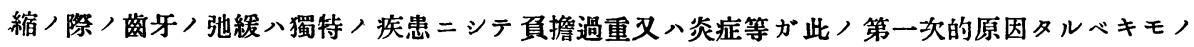
ニアラズ。第一次的員擔過重ノ總テノ被害八炎症ナキ場合ニ於ケルト全ク同樣二修復セラル。炎 症二依りテ消失シタル支持組糡八永久二消失シタルモノニシテ, 此, 範圍二於テハ蒛牙，骨植八 被害セラル。慢性炎症が苜牙附近組轼ノ著シキ障碍ヨ起サシムル限り支持組織/整復ニョリテ晚 期弛緩 7 起サシメ得。此ノ形ノ弛䌅八第一次的弛紱卜ハ全ク異リタルモノナリ。又一般的二幼若

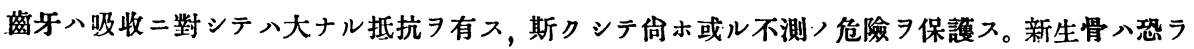
ク堅迫ニョル吸收二對シテハメ大ナル抵抗ヨ有スルモノナル心゙シ。（檜垣）

\title{
英科馀療「ガード
}

Zahnärztlich Therapeutische Kartothek.

Prof. Dr. H. J. Mamlok und Dr. H. E. Bejach, Berlin.

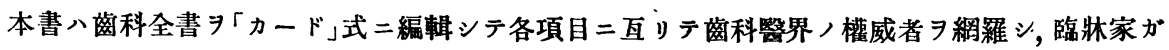

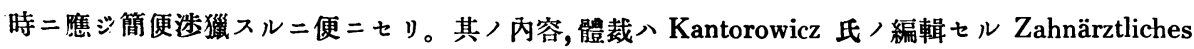
Wörterbuch 二似タルモ，載錄セラレタル項目传カニ多數ニシテ然カモ簡單明暸ナル點二於テ臨 牀家/好琴考書タリ，且ッ「カード」式ナルヨ以テ Kantorowicz 氏 Wörterbuch 二見ル引用，複 雑サヨ避ケテ極メテ簡便ナリ。 
本書八1930 年ヨリ Korrespondenzblatt 誌/主幹 Mamlok 氏下 Zahnärztliche Rundschau ノ圭幹ニシテ世界齒科制度ノ權威者タル Bejach 氏ノ共同編輯二係》，各項目ノ執筆者八獨冕 語 以テ醫學ヨ教育スル諸國郎チ獨遠，瑞西，墺地利，匈牙利及ビチェッコスラビアキヤ〉諸大 家ニシテ例バ莮科二關スル執筆者ノ姓名ヨ舉グレバ Doz. Balter(Bonn), Dr. Herzog (Allendorf) Dr. Steiner(Wien), Prof. Hesse(Jena), Doz. Schultz (Charlottenburg-Westend), Prof. Müller (Berlin), Prof. Jung(Berlin), Dr. Fenchel(Freiburg), Prof. Baetzner(Berlin), Dr. Schmitz (Köln), Prof. Reinmöller(Rostock), Dr. Adler(Berlin), Prof. Axhausen(Berlin), Dr. Kukulius (Düsserdorf), Prof. Moral(Rostock), Dr. Landsberger(Berlin), Doz. Münzheimer, Dr. Sebba (Danzig), Dr. Kerpel(Wien), Dr. Stärke(Berlin), Dr. Bejach (Berlin), Dr. Faust(Hannover), Dr. Toluck(Frankfurt), Prof. Hille(Leipzig), Dr. Scherbel(Leipzig), 'Dr. Levy(Berlin), Prof. Salamon(Budapest), Dr. de Terra(Türich), Dr. Kunnert(Breslau), Dr. Goldberger(Wien), Prof. Praeger(Tübingen), Doz. Jonas(Leipzig), Dr. Austerlitz, Dr. Trebitsch(Berlin), Dr. Spanier (Karlsruhe), Dr. Kaufmann(Mannheim), Dr. Smrecker(Wien), Prof. Greve(Erlangen), Dr. Spanner(Pforzheim), Prof. Schoenbeck(Berlin), Dr. Heinemann(Rathenom), Prof. Boenheim (Berlin), Dr. Rosenzweig(Wien), Dr. Oetlinger(Stettin), Dr. Rothschild(Berlin), Prof. Neumann.(Berlin), Prof, Türkheim(Hamburg), Dr. Levin, Dr. Wessmund(Berlin), Dr. Chaim (Berlin), Dr. Phillip(Lüneberg), Dr. Hruska(Mailand), Dr. Nussbaum(Berlin), Doz. Pflüger (Hambury ), Doz. Oppler, Prof. Folk(München), Dr. Schlemmer(Wien), Dr. Guttmann(Berlin), Prof. Fritz, Prof. Munk 等ノ諸氏ナリ。

全「カード」ニ八第一二各項目，ABC順ニョル索引アリ。之ニョリテ自己が檢セントスル項 目が何部二屬スルカヨ知ルヨ得。全「カード」ハ次ノ八部二分類セラル。

1. A 部 梱科概論及ビ各論

2. B 部 隣接醫學

3. C 部 器具及ビ器械

4. C'部 器具及ビ器械, 工業上ノ指針

5. D部 藥品及ビ材料

6. $\mathrm{D}^{\prime}$ 部。藥品及ビ材料ノ工業上ノ指針

7. $\mathrm{F}$ 部 雜部

8. E 部 化學及ビ藥種

第一ノ $\mathrm{A}$ 部二於テ蓄科醫學二關スル總テノ項目 7 擧ゲ, 短キハー枚ノ「カード」, 長キハ八枚ノ 「カード」ニ極メテ要領ヨク簡明ヨまトシテ記載セリ。第二ノ B 部ニ於テハ齒科二直接關係アル事 項或ハ蒛科醫トシテ知ラザルベカラザル一般醫學, 常識トモナルベキ各項ヨ擧ゲタリ。例へバ腺

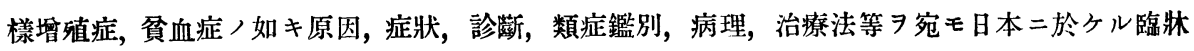


整典ノ程度二載錄セり。特二特色トシテ見ルベキハ第四ノ $\mathrm{C}^{\prime}$ 部卜第六ノ $\mathrm{D}^{\prime}$ 部ナリ。 $\mathrm{C}^{\prime}$ 部二於 テハ最近發賣セラル、ニ至リタル器具, 器悈類ノ夫ナル名稱ノモノヨ舉ゲ, 用法, 特徵, 製造所, 販賣所，定價等 7 擧ゲ, $D^{\prime}$ 部二於テハ新菜其/他ノシナル名稱 7 擧ゲ，化學的性分，適應症，用 量, 販賣セラル形態，散藥ナリヤ，水䒚ナリヤ，製造合社等ヨ擧ゲテ專ラ臨林家ノ便宜ヨ計ル 以テ目的卜七リ。（㭘垣）

\section{Tratado de Odontologia Practica}

Prof. Dr. J. Szabó 1932, Barcelona

戰前歐洲二於テー方, 覇 $コ$ 稱へテ居タアルケヴィ(Arkövy) 教授ノ後繼者デアル，本著者サア

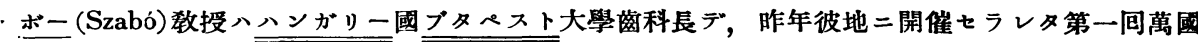

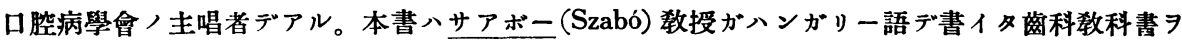
アドルフォヴェレラ(Adolfo Varela) 氏ガスヘイン語ニ譯シバルセロナ市グスタフォギリー (Gustavo Gili)書店カラ出版七ラレタモノデアル。本書八旣ニイタリー語二譯セラレテ出版セラ レテ居ル。

本書八六百八十七頁 $=$ 涉ル大册デ, 其/誐明二用ヒラレテ居ル附圖 數八六百十一二及ンデ居 ル。但シ此ノスヘイン版ニ於テハ寫㠱版、復寫ニ依りタルモノラシク稍 、不鲜明デハアルガ, 著者獨特八圖が多イ。

本書八大體ニ於テ三大部門二分ヶテ書カレテ居ル。第一八解剖ニシテ, 發生, 形態二就イテ先

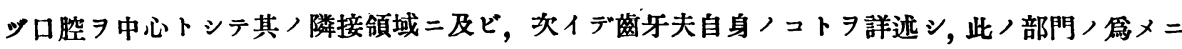

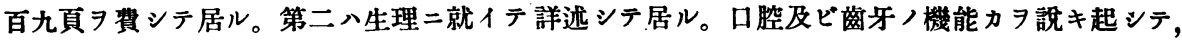
各個㖑器, 生物學機辖 轉习簡單明暸二要領ヨクマトメテアルコト本書，如キハ他二例が無1。第三ニ於テ八病理及ビ

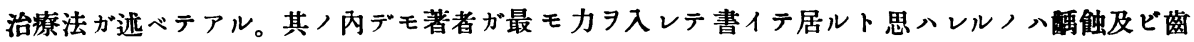

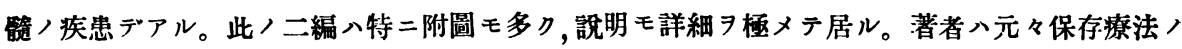
㚼ノ人デアルノデ保存治療法二關シテハ極メテ廣篹圍二種々ノ方法ヨ批制シテ述ベテ居ル。充

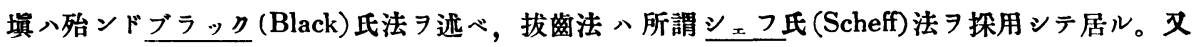
拔去法 ノ次二創傷治癒二就イテ比較的詳迅シテ居ルが, 之八著者ノ教室ノ研究デアル。

以上ノ外二本書二八約十個ノ表が揭ゲテアッテ，馀療醫典式ニ一見制然トスル方法モ探ッテ アル。之八學生ニトツテハ極メテ便宜デアル。

要スルニ本書八主トシテ學生ヨ主體トシテ書カレタモノ、如ク，他ノ何レノ教科書二比シテ

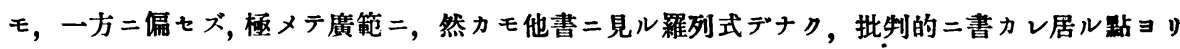
シテ, 恐ラク数科書トシテハ最上級ノ者ノーツデアラウ。唯唓遍的ニナッテ居ル篇メニサアボ二 (Szabó)教授ノ個性が極メテ裳朧タル處ハ亦止ムヨ得又點デアラウ。(桧垣) 